\title{
COMPUTER-AIDED DECISION-MAKING IN CONSTRUCTION PROJECT DEVELOPMENT
}

\author{
Mariola Violeta KSIĄŻEK ${ }^{\mathrm{a}}$, Paweł Olaf NOWAK ${ }^{\mathrm{a}}$, Serkan KIVRAK ${ }^{\mathrm{b}}$, \\ Jerzy Hubert ROSŁON ${ }^{\mathrm{a}}$, Leonas USTINOVICHIUS ${ }^{\mathrm{c}}$ \\ ${ }^{a}$ Division of Construction Engineering and Management, Institute of Building Engineering, \\ Civil Engineering Faculty, Warsaw University of Technology, Armii Ludowej 16, 00-637, Warsaw, Poland \\ ${ }^{b}$ Civil Engineering Department, Faculty of Engineering, Anadolu University, Iki Eylul Campus, \\ 26555 Eskisehir, Turkey \\ ${ }^{c}$ Vilnius Gediminas Technical University, Sauletekio al. 11, LT-10223 Vilnius, Lithuania
}

Received 20 Oct 2014; accepted 19 Nov 2014

\begin{abstract}
One of the most difficult problems in construction is taking objective decisions. A decision-making process is very complicated and time consuming (due to the complex nature of construction projects). Many experts with extensive knowledge of construction industry take subjective decisions related to verbal methods of decision-making. Difficulties are related mostly to the creation of a set of relevant criteria, providing answers to the decision-maker's questions. A set of proper criteria and mathematical tools (such as computer calculation algorithms with multi-criteria analysis) could significantly improve objective decision-making. The paper presents ESORD - an informatics tool allowing to establish a hierarchy (ranking) of different types of solutions on the basis of mathematical calculation. The authors present a comparison of different methods used for multi-criteria decision-making.
\end{abstract}

Keywords: informatics tool, construction projects, multi-criteria decision-making, investment variants.

\section{Introduction}

One of the main problems faced by every investor/project manager is selecting an implementation variant for an investment project. The difficulty related to this issue emerges as early as at the stage of investment preparation, once requirements and expectations of the investor are defined in the functional-utility program. At individual stages of the lifecycle of an undertaking, analysed phenomena are very complex, which is mainly due to specific traits, characteristics, complexity and nature of construction processes and relations between them. On the other hand, a description of these relations is based mainly on expert opinions and should take into account both measurable factors and those difficult to measure (Ustinovichius et al. 2006; Kildiene et al. 2014; Vodopivec et al. 2014); besides, its quality depends largely on expert knowledge and experience of decision-makers.

The issue of decision-making constitutes an integral part of every field of science and art. A decision-making process is an activity which results in taking a specific decision. The entity involved in a decision-making process is a decision-maker, expressing specific preferences, assessing possibilities and results, and choosing the final decision-making variant (Książek 2010a; Tyszka 1986; Brown 2012; Yazdani-Chamzini et al. 2013a; Ustinovichius et al. 2011; Ghosh et al. 2012). Analysis of the decision-making situation is the first task of a decisionmaker. The decision-making situation is a set of all elements, dependent on and independent of an assessor, which exert impact on the decision to be made. In the process of formulation of the decision-making problem, factors independent of a decision-maker include a set of variants to be examined (the so-called conditions restricting the decision), while factors dependent upon the decision-maker include criteria for assessment of solutions, described by technical and economic indicators, most adequate for the given decision-making situation, expressed in specific units (Zavadskas et al. 2014b; Yazdani-Chamzini et al. 2013b; Zolfani et al. 2013).

Assessment of characteristics of a given variant may be both quantitative (objective) and qualitative (difficult to measure) (Ustinovichius 2004; Simanavičienè et al. 2014). The difficulty in decision-making is not only due to the level of complexity of a task as well as complexity and designation of variants, but also - expectations of the assessing person. On the other hand, preferences of the expert are largely dependent on the point of view of the decision-maker who has caused development of the given opinion or assessment. The authors believe that due to the above reasons, computer-based implementation of calculation algorithms of selected methods of assessment and ranking of solutions is an efficient tool that allows to obtain aggregated variant assessments and results in a more 
efficient decision-making process. Detailed information concerning the issues of valuation of criteria, as well as the psychological aspect of decision-making has been presented in Brauers et al. (2013), Hashemkhani et al. (2013), Ustinovichius et al. (2007), Tyszka (1986) and Zavadskas et al. $(2012,2014 a)$.

\section{Main assumptions of the methodology of assessment and ranking of solutions in the construction trade}

According to the authors, the calculation algorithms of various types of methods of multi-criteria assessment and the theoretical apparatus - including sociology, psychological theory of decision-making and decision-making analysis - contribute to greater effectiveness of the decision-making process, and allows for avoidance of substantial mistakes that could interfere with the quality and reliability of the decision made. In practice, individual tools are often used selectively, which often garbles the assessment results. Experts are expected to make assessments in accordance with their professional knowledge and the construction art - reliable, objective and considering the specific character of the given decision-making situation. It would be difficult, however, to clearly define individual preferences, system of values, and motivations of an expert. Expert opinions are formulated on the basis of their knowledge and experience, and they depend upon such factors as availability of information and the level of complexity of the task, emotional state and mood, selfesteem and susceptibility to group influence, and the mode of perception of a given phenomenon (Ustinovichius 2007; Turskis et al. 2013; Zavadskas et al. 2014a).

Sometimes, difficulties associated with decisionmaking arise from an assessor's fear to assume responsi- bility, make a mistake or be rejected by the community. Therefore, in order to as much as possible eliminate the causes of interference with decisions made, an original survey of decision-maker preferences has been developed, as well as the decision-making variant ranking procedure, implemented as the ESORD calculation tool (Expert System for Assessment of Developer Solutions) (Tyszka 1986; Kozielecki 1977). In the opinion of the authors, the purpose of the survey developed within the framework of this research was - in the first place - to clearly and precisely define criteria for assessment of variants, referring to the problem of selecting the best investment (e.g. premises, building) from the perspective of expectations particular to potential recipients (users) (Peng, Tzeng 2013; Zalewska, Zalewski 2012).

\section{IT tool to support decision-making in the construction industry}

The ESORD IT tool contains groups, types and kinds of criteria entered into the system, which have been defined in accordance with the aspect of selection of the apartment (house) variant with reference to preferences of potential purchasers and users.

Figure 1 presents the overall block diagram of algorithms used by ESORD, using the variant ranking methods (Książek 2010b, 2011).

\subsection{Algorithm solving the presented problem}

As a result of conducted surveys, the basic group of criteria for the assessment of residential construction facilities (Table 1) was formed and separated, together with definition of the levels of importance of the features suggested in

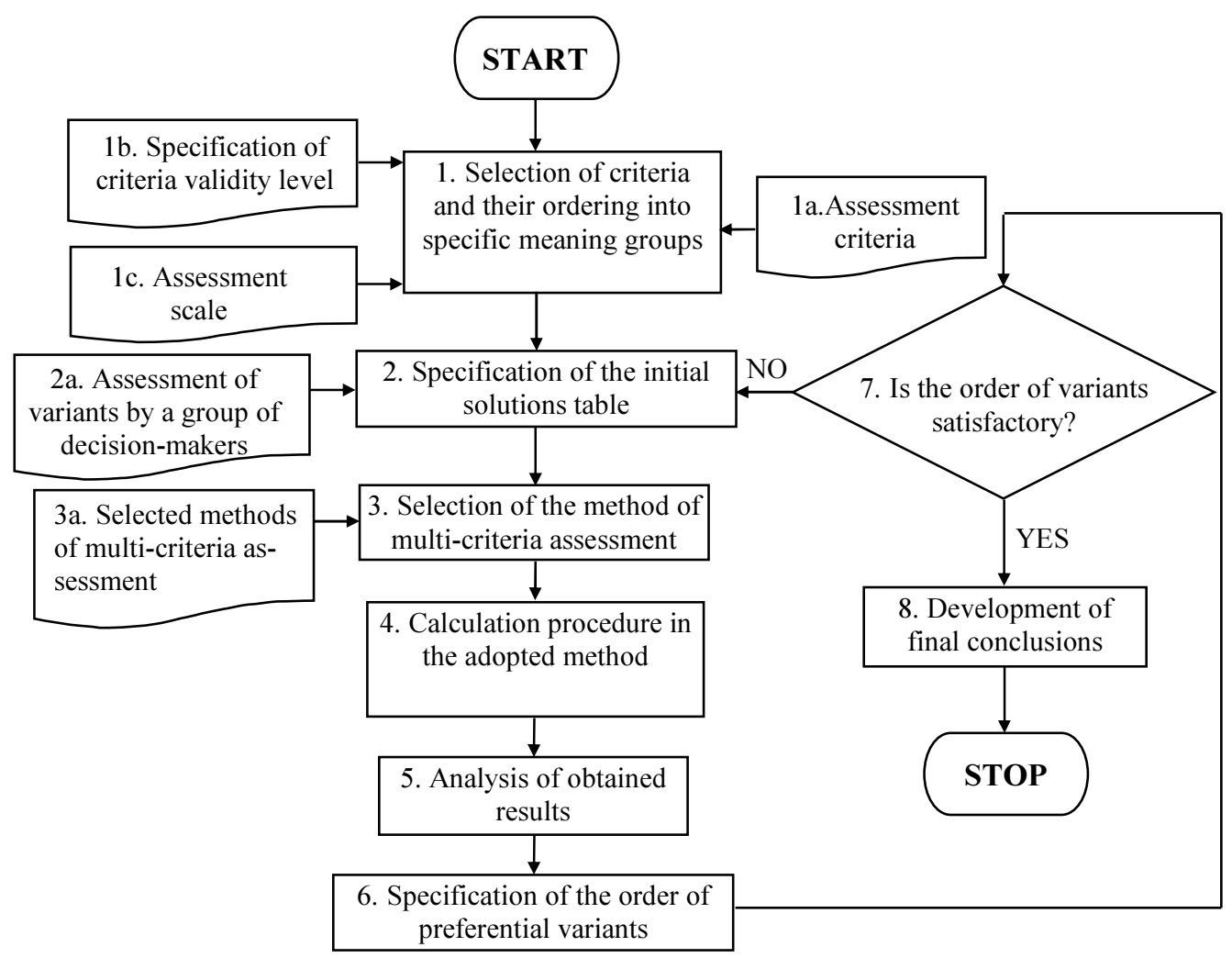

Fig. 1. General chart of activities during the assessment of decision variants 


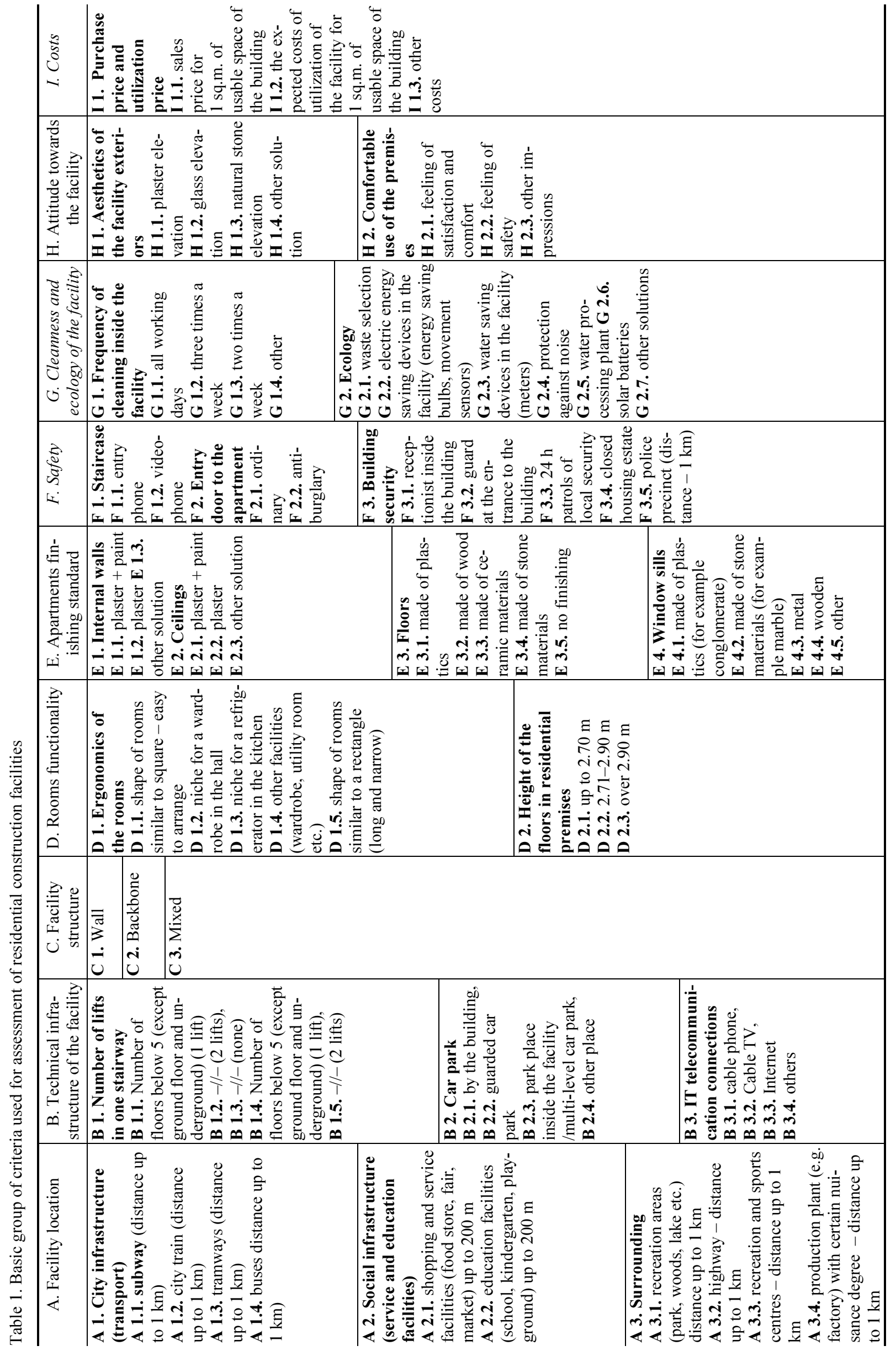


Table 2. Apartment database

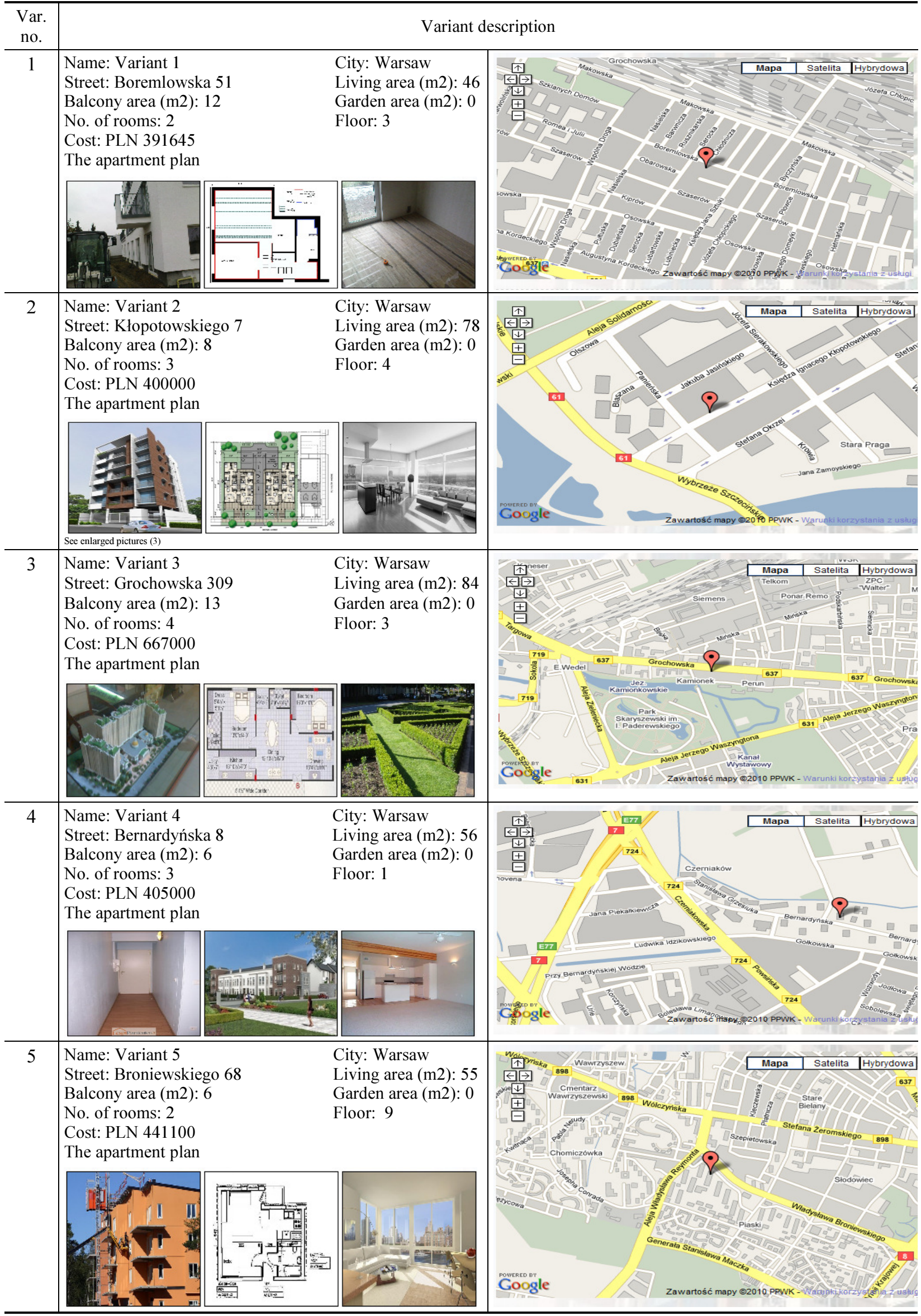


Continued Table 2

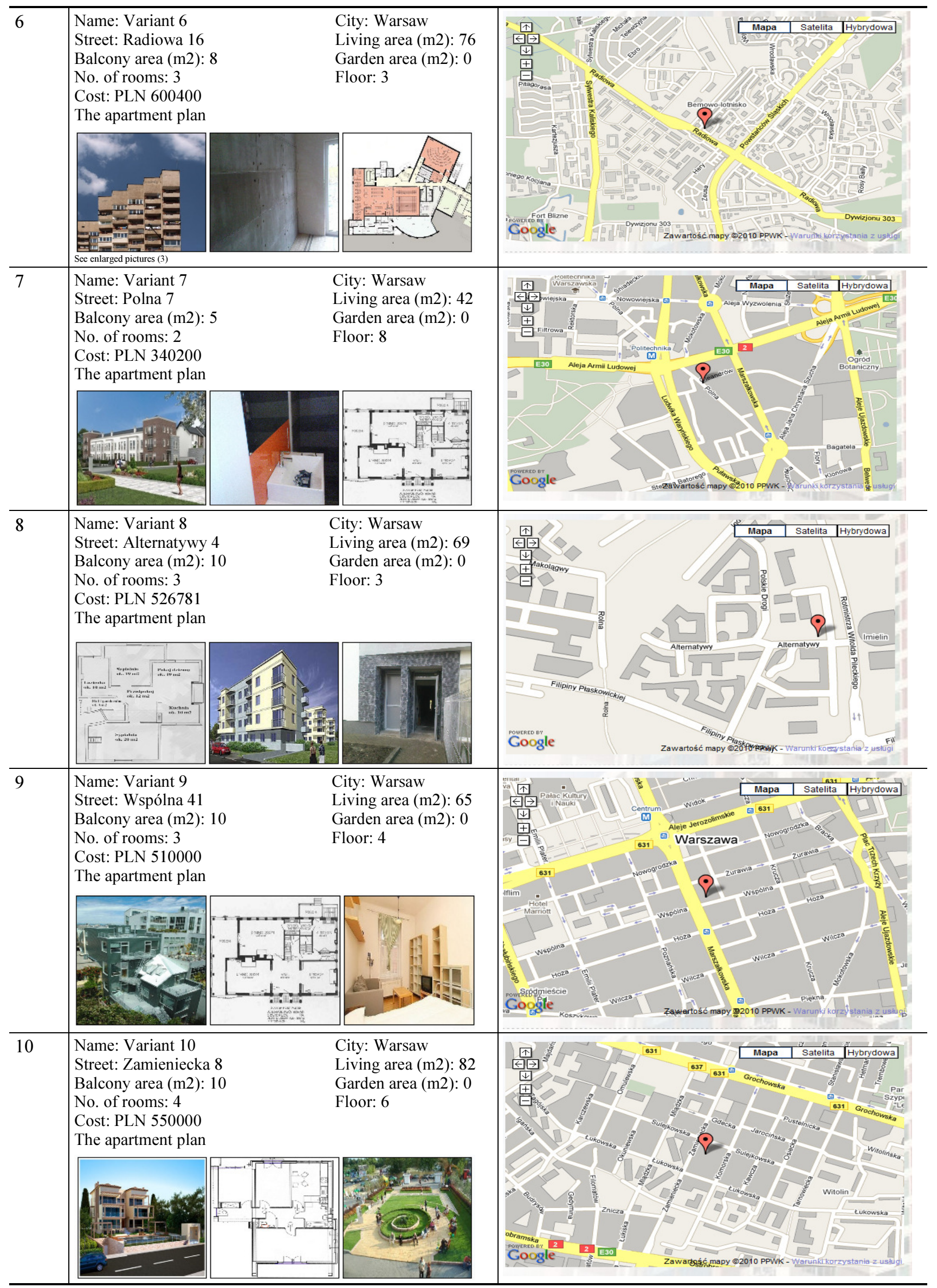


the survey, using the preferences specified by respondents. The collection of criteria segregated into importance groups, their importance levels and preferences defined by decision-makers with respect to a residential construction facility constitute the starting point for the methodology of solution assessment suggested by the authors.

In the opinion of the authors, it will be possible to improve prioritisation of the solutions and select the best one using the obtained survey results, correlated using a supporting IT tool.

ESORD orders the variants using the entire group of implemented assessment method algorithms or using only those indicated by the user (decision-maker). As a result, one receives a table and a visual presentation of results in the form of aggregated assessments (resulting from the use of a given group of methods) and classification of the considered variants using each of the methods of multicriteria assessment.

Figure 1 presents the general chart of activities during the assessment of decision variants within the framework of the suggested methodology.

In order to arrange the project variants, the following multi-criteria assessment methods were applied: ELECTRE (Roy 1991), ideal point (Hwang, Yoon 1981; Zalewski 2013), AHP (Saaty 1994; Gudienè et al. 2014), total, weighted total (MacCrimmon 1968), and the method using elements of fuzzy logic (Zadeh et al. 1975; Zadeh 1978; Corriere et al. 2013; Radziszewska-Zielina 2011; Kaya, Kahraman 2014). In order to implement the suggested methodology, the ESORD IT tool was developed (Expert System of Developer Solutions Assessment). The software uses algorithms of the above-listed methods and detailed results of surveys that constitute the basis to define the level of importance of specific criteria. This chapter presents performance of specific calculations leading to prioritisation of the considered variants, using numeric examples from the ESORD IT tool (Książek 2010c).

The above chart was expanded so that IT implementation of algorithms of specific methods of assessment to the ESORD software was possible.

\subsection{Input data for all methods}

Input data for all calculation methods constitute:

1. Calculation algorithms of methods (Książek 2010b, 2011; Książek, Nowak 2009).

2. List of criteria (described in Table 1) assessed by a group of respondents within the framework of surveys conducted by the authors (Krzemiński, Książek 2008).

3. Criteria importance levels (obtained on the basis of preferences specified by the respondents within the framework of surveys conducted by the authors and generated by ESORD).

4. A collection of decision variants implemented in the system, subject to assessment (the so-called apartment database presented in Table 2).

5. Survey of decision-maker's preferences concerning the examined residential construction facility (Książek 2010a).
ESORD calculates the so-called main weights vector for specific criteria in order to determine the level of their completion. In order to determine the vector, the following marks were adopted for the main criteria: $K^{L}-$ assessment of Type 1 user for the Facility location criterion; $K^{I n}$ - assessment of Type 1 user for the Technical infrastructure of the facility criterion; $K^{K o}$ - assessment of Type 1 user for the Facility structure criterion; $K^{F}$ assessment of Type 1 user for the Rooms functionality criterion; $K^{S}$ - assessment of Type 1 user for the Apartments finishing standard criterion; $K^{B}$ - assessment of Type 1 user for the Safety criterion; $K^{C}$ - assessment of Type 1 user for the Cleanness and ecology of the facility criterion; $K^{O}$ - assessment of Type 1 user for Attitude towards the facility criterion; $K^{K}$ - assessment of Type 1 user for the Costs criterion; $W^{L}$ - the main weights vector index value for the Facility Location criterion.

The specific main weights indexes for the criteria are calculated using the following formula:

$W^{N K}=\frac{K^{N K}}{\left(K^{L}+K^{I n}+K^{K o}+K^{F}+K^{S}+K^{B}+K^{C}+K^{O}+K^{K}\right)}$,

where: $N K$ - name (mark) of a given criterion.

Therefore, for example, the value of $W_{i}^{L}$ index in relation to the Facility location criterion is calculated in the following way:

$W^{L}=\frac{K^{L}}{\left(K^{L}+K^{I n}+K^{K o}+K^{F}+K^{S}+K^{B}+K^{C}+K^{o}+K^{K}\right)}$.

It should be noted that while calculating the main weights vector, the system does not include the weights value for detailed criteria. For main criteria, the received results are presented in Table 3.

Table 3. Main criteria weights vector

\begin{tabular}{l|c|l|c}
\hline \multicolumn{1}{c|}{ Criterion } & Weight & \multicolumn{1}{|c}{ Criterion } & Weight \\
\hline Facility location & 0.143 & \multicolumn{1}{|c}{ Safety } & 0.143 \\
\hline $\begin{array}{l}\text { Technical infrastruc- } \\
\text { ture of the facility }\end{array}$ & 0.107 & $\begin{array}{l}\text { Cleanness and } \\
\text { ecology of the } \\
\text { facility }\end{array}$ & 0.107 \\
\hline Facility structure & 0.036 & $\begin{array}{l}\text { Attitude towards } \\
\text { the facility }\end{array}$ & 0.107 \\
\hline Rooms functionality & 0.143 & Costs & 0.107 \\
\hline $\begin{array}{l}\text { Apartments finishing } \\
\text { standard }\end{array}$ & 0.107 & & \\
\hline
\end{tabular}

\subsection{Calculations for the selected assessment methods}

ESORD software has implemented calculation algorithms of the selected methods of multi-criteria assessment including the average (total) method, weighted average (weighted total) method, ELECTRE method, ideal point 
method, AHP method and the calculation method using fuzzy logic.

Assessment of each criterion is made in accordance with the following dependence:

$$
k_{i j}^{N K}=\left(O_{i j}^{I}\right)_{N K}^{2} \cdot\left(O_{i j}^{I I}\right)_{N K}^{2},
$$

where: $k_{i j}^{N K}$ - assessment value for $N K$ criterion, where the $i j$ indexes mean specific sub-criteria presented on the examples below; $\left(O_{i j}^{I}\right)_{N K}-N K$ criterion assessment meeting the expectations of Type 1 user; $\left(O_{i j}^{I I}\right)_{N K}-N K$ criterion assessment given by Type 2 user; $n$ - means the $n$ sub-criterion within a given $N K$ criterion.

Raising the point assessment of a given criterion to a power was introduced to the system in order to enable more extensive differentiation of the final assessments of variants. In order to calculate values of the assessments of the considered decision variants for specific criteria, the system performs calculations in accordance with the dependence presented below:

$$
W_{w}^{N K}=\frac{\sum_{n=1}^{r}\left(k_{i j}^{N K}\right)_{n}}{\sum_{n=1}^{r}\left(\max k_{i j}^{N K}\right)_{n}} ; w=(1, \ldots, 10), \quad n=1,2, \ldots r,(4)
$$

where: $W_{w}^{N K}$ - assessment of " $w$ " variant according to " $N K$ " criterion.

Based on the conducted calculation procedure, the system generates the results of ordering specific decision variants subject to assessment. The final assessments for specific solutions received after using the methodology are presented in Table 4 . Table 5 contains a visual presentation of the orders of preferential variants generated by ESORD for specific assessment methods.

Table 4. Collective presentation of final variant assessments for all methods

\begin{tabular}{c|c|c|c|c|c|c}
\hline $\begin{array}{c}\text { Variant } \\
\text { method }\end{array}$ & $\begin{array}{c}\text { Weighted } \\
\text { average }\end{array}$ & Average & $\begin{array}{c}\text { Ideal } \\
\text { point }\end{array}$ & Electre & $\begin{array}{c}\text { Fuzzy } \\
\text { logic }\end{array}$ & AHP \\
\hline Variant 1 & 0.114 & 0.115 & 0.123 & 0.172 & 0.120 & 0.121 \\
\hline Variant 2 & 0.107 & 0.106 & 0.116 & 0.207 & 0.112 & 0.104 \\
\hline Variant 3 & 0.091 & 0.093 & 0.092 & 0.0001 & 0.077 & 0.090 \\
\hline Variant 4 & 0.097 & 0.097 & 0.105 & 0.0001 & 0.104 & 0.095 \\
\hline Variant 5 & 0.097 & 0.098 & 0.074 & 0.138 & 0.084 & 0.096 \\
\hline Variant 6 & 0.102 & 0.100 & 0.099 & 0.034 & 0.096 & 0.102 \\
\hline Variant 7 & 0.105 & 0.104 & 0.115 & 0.103 & 0.118 & 0.101 \\
\hline Variant 8 & 0.102 & 0.101 & 0.102 & 0.103 & 0.113 & 0.104 \\
\hline Variant 9 & 0.083 & 0.084 & 0.063 & 0.0001 & 0.057 & 0.084 \\
\hline Variant 10 & 0.103 & 0.103 & 0.110 & 0.241 & 0.121 & 0.102 \\
\hline
\end{tabular}

Table 5. Visualization of the order of preferential variants for applied methods

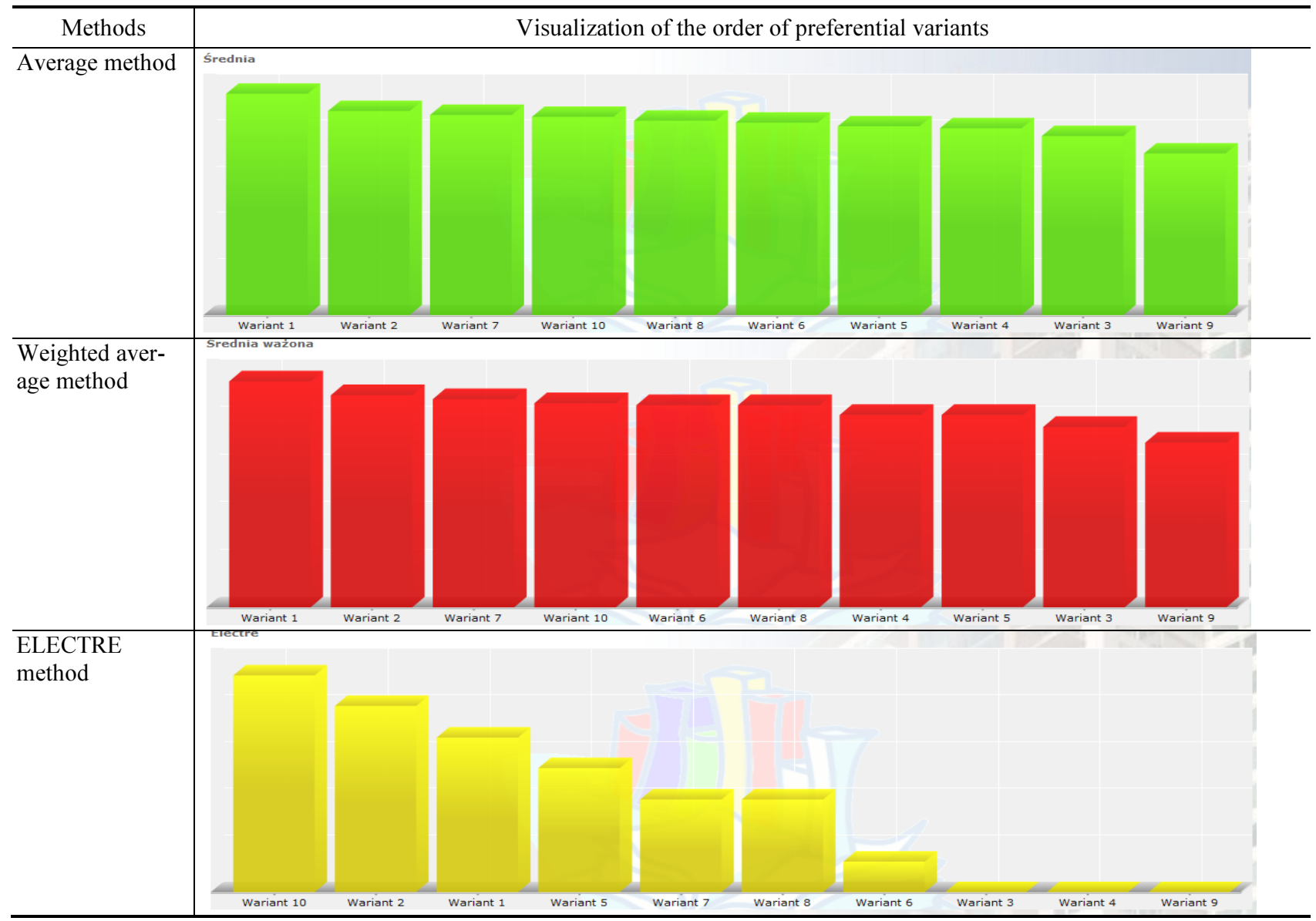


Continued Table 5

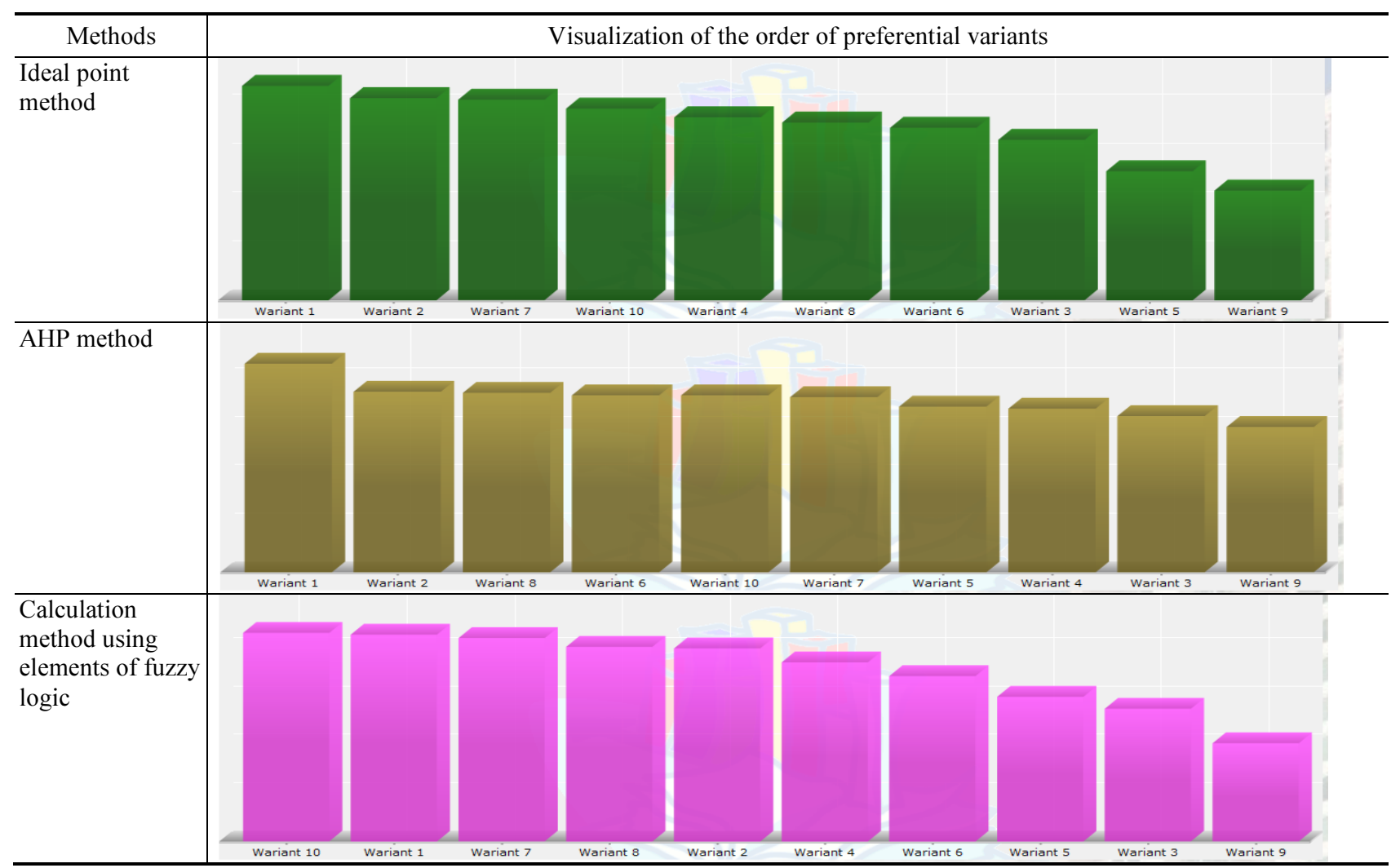

Table 6. List of preferential variants ordered from the best to the worst (variant, city, street, price and assessment)

\begin{tabular}{c|l|l|r|r}
\hline Variant & City & Address & Price & Assessment \\
\hline Variant 1 & Warsaw & Boremlowska 51 & 391645 & 518 \\
\hline Variant 2 & Warsaw & Klopotowskiego 7 & 400000 & 409 \\
\hline Variant 3 & Warsaw & Zamieniecka 8 & 550000 & 320 \\
\hline Variant 4 & Warsaw & Polna 7 & 340200 & 286 \\
\hline Variant 5 & Warsaw & Alternatywy 4 & 526781 & 194 \\
\hline Variant 6 & Warsaw & Radiowa 16 & 600400 & 120 \\
\hline Variant 7 & Warsaw & Bernardynska 8 & 405000 & 71 \\
\hline Variant 8 & Warsaw & Broniewskiego 68 & 441100 & 67 \\
\hline Variant 9 & Warsaw & Grochowska 309 & 667000 & 10 \\
\hline Variant 10 & Warsaw & Wspolna 41 & 510000 & 0 \\
\hline
\end{tabular}

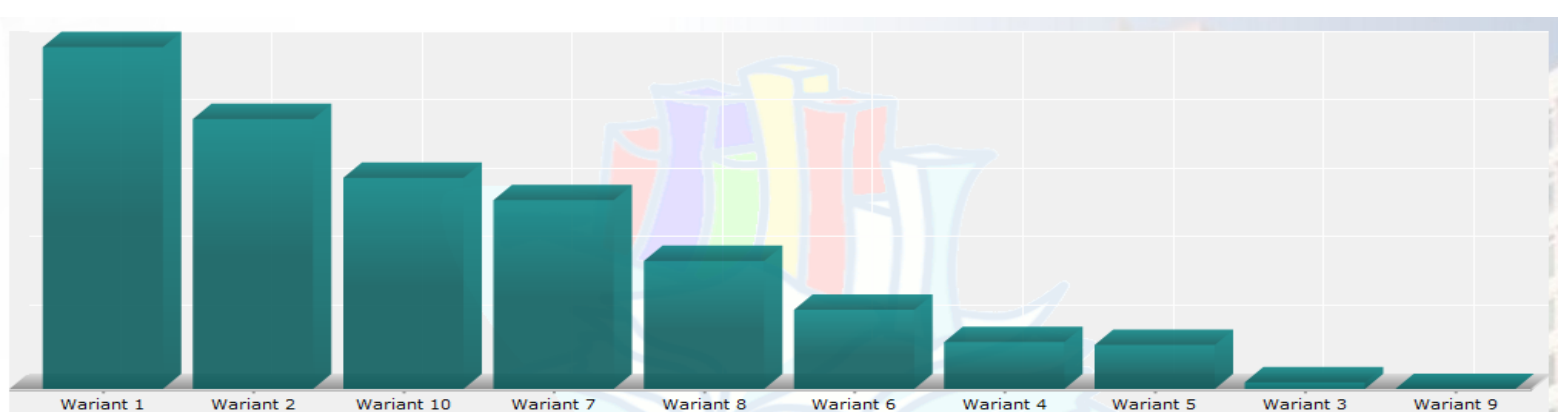

Fig. 2. Visualization of the obtained order of preferential variants

\section{Comparative analysis of the obtained results of variant assessment}

Expert assessment was applied to ten decision variants introduced to ESORD system. Their detailed description is included in Table 2. The analysis of the obtained results was conducted using the selected methods of multi-criteria analysis (average, weighted average, ELECTRE, ideal point, AHP and the calculation method using fuzzy logic).

Table 6 presents the obtained list of preferential variants ordered from the best to the worst. Figure 2 presents the obtained order of the analysed solutions. 
Table 7. Assessment of the correlation level of the results pertaining to assessed examples of decision variants in the form of numerical values of $\cos \theta$

\begin{tabular}{l|c|c|c|c|c|c}
\hline & Weighted average & Average & Ideal point & Electre & Fuzzy logic & AHP \\
\hline Weighted average & 1 & 0.998 & 0.896 & 0.892 & 0.81 & 0.931 \\
\hline Average & 0.998 & 1 & 0.896 & 0.891 & 0.801 & 0.933 \\
\hline Ideal point & 0.896 & 0.896 & 1 & 0.905 & 0.824 & 0.832 \\
\hline Electre & 0.892 & 0.891 & 0.905 & 1 & 0.744 & 0.915 \\
\hline Fuzzy logic & 0.810 & 0.818 & 0.824 & 0.744 & 1 & 0.738 \\
\hline AHP & 0.931 & 0.933 & 0.832 & 0.915 & 0.738 & 1 \\
\hline
\end{tabular}

Table 8. Assessment of the correlation level of the results pertaining to assessing examples of decision variants in linguistic form

\begin{tabular}{l|c|c|c|c|c|c}
\hline & Weighted average & Average & Ideal point & Electre & Fuzzy logic & AHP \\
\hline Weighted average & Very high & Very high & Medium & Medium & Low & High \\
\hline Average & Very high & Very high & Medium & Medium & Low & High \\
\hline Ideal point & Medium & Medium & Very high & High & Low & Low \\
\hline Electre & Medium & Medium & High & Very high & Low & High \\
\hline Fuzzy logic & Low & Low & Low & Low & Very high & Low \\
\hline AHP & & & & & Low & Very high \\
\hline
\end{tabular}

\section{The comparison of results obtained by different methods}

The results of ordering decision variants were subject to analysis using two selected methods - A and B. For example, specific A and B methods generate the obtained ranking of solutions in the following form:

- method A: [Variant 1, Variant 5, Variant 3,

Variant 2, Variant 4];

- method B: [Variant 2, Variant 1, Variant 5,

Variant 4, Variant 3].

$\mathrm{A}$ and $\mathrm{B}$ methods may be compared by calculating $\cos \theta$, namely, the angle between their vectors in accordance with the dependence:

$$
\cos \theta:=\frac{\mathbf{A} \cdot \mathbf{B}}{|\mathbf{A}||\mathbf{B}|},
$$

where: $|\mathbf{A}||\mathbf{B}|$ - lengths (norm, value) of vectors A and B; $\mathbf{A} \cdot \mathbf{B}$ - the scalar product of vectors $\mathrm{A}$ and $\mathrm{B} ; \cos \theta-$ the angle between vectors $\mathrm{A}$ and $\mathrm{B}$.

Tables 7-8 present the assessment of the correlation level of the ordering results for variant examples for the selected multi-criteria assessment methods in the linguistic form, and the numerical values reflecting them $\cos \theta$.

The analysis of correlation of the results pertaining to ordering examples of decision variants for the selected multi-criteria assessment methods (Table 9) shows that specific numerical values fall between 0.738 and 0.999 . Therefore, in order to compare correlation levels of the results within the framework of the assessment methods used in the calculation procedure, the following thresholds were adopted:

- below 0.85 - low correlation of results;

$-0.85-0.94-$ medium correlation;

-0.95 - high correlation;

- over 0.95 - very high correlation.
The ESORD software generates assessments based on thresholds adopted by the authors. Order of specific variants obtained using each of the methods is presented in Table 9.

Table 9. Classification of variants within the framework of selected assessment methods

\begin{tabular}{l|l}
\hline & $\begin{array}{c}\text { Order of variants received within } \\
\text { the framework of specific methods }\end{array}$ \\
\hline Average method & $1 \succ 2 \succ 7 \succ 10 \succ 8 \succ 6 \succ 5 \succ 4 \succ 3 \succ 9$ \\
\hline $\begin{array}{l}\text { Weighted average } \\
\text { method }\end{array}$ & $1 \succ 2 \succ 7 \succ 10 \succ 6 \succ 8 \succ 4 \succ 5 \succ 3 \succ 9$ \\
\hline ELECTRE method & $10 \succ 2 \succ 1 \succ 5 \succ 7 \succ 8 \succ 6 \succ 3 \succ 4 \succ 9$ \\
\hline Ideal point method & $1 \succ 2 \succ 7 \succ 10 \succ 4 \succ 8 \succ 6 \succ 3 \succ 5 \succ 9$ \\
\hline AHP method & $1 \succ 2 \succ 8 \succ 6 \succ 10 \succ 7 \succ 5 \succ 4 \succ 3 \succ 9$ \\
\hline Fuzzy logic & $10 \succ 1 \succ 7 \succ 8 \succ 2 \succ 4 \succ 6 \succ 5 \succ 3 \succ 9$ \\
\hline
\end{tabular}

Based on the conducted analysis of correlation of results for the specific methods, it was stated that:

- Very high correlation occurs between the results of average and weighted average method. In the case of those methods, the order of the first three variants is the same, namely: $1 \succ 2 \succ 7$.

-High correlation occurs between the results of ELECTRE, ideal point and AHP methods. For those methods, variant 2 was placed on the second place in the classification. In the ELECTRE method, variant 10 was on the first place, while for AHP and ideal point methods, variant 1 was the best. The specifics of ordering solutions in the ELECTRE method is that at the last stage of the calculation procedure, the calculations are made in a binary system, so the variants with slightly differentiated assessment may become equal (for example variant 7 and 8 or variants 3, 4 and 9). High correlation occurs also between the results of AHP, total and weighted total methods.

- Medium correlation occurs between the results of ELECTRE, entropy, total and weighted total meth- 
ods. Although in the case of the above methods (apart from ELECTRE), the order of the three first variants is the same (namely $1 \succ 2 \succ 7$ ), the differences in their assessments are quite significant, presumably because of high differentiation of the calculation algorithms. In the ELECTRE method, the order of the three first variants is different only because variant 10 is in the first place, namely $10 \succ 2 \succ 1$.

-Low correlation occurs between the results of the method using the elements of fuzzy logic, ideal point, entropy, total, weighted total, ELECTRE and AHP. For the method using elements of fuzzy logic and ELECTRE, variant 10 is the best. For the remaining methods, variant 1 is the best. Further order of the objects is as follows: $2 \succ 1 \succ 5$ for ELECTRE method and $1 \succ 7 \succ 8$ for the method using fuzzy logic. In the case of average, weighted average and ideal point methods - the order of the first three preferential variants is the same, namely, $1 \succ 2 \succ 7$. For AHP method, the order of the first three preferential variants is as follows: $1 \succ 2 \succ 8$.

In the opinion of the authors, the approach of an average software user towards the obtained order of decision variants is important. Based on the above calculation example, it can be stated that among ten examples of apartments which were considered, variants with numbers $1,2,7$ and 10 in all methods (apart from variant 7 in ELECTRE method and variant 2 in the method using fuzzy logic) were ordered (in various sequences) on the places from 1 to 4 . For example, the variants with numbers 1 and 2 were the best for six of the considered methods. Variant 7 was placed on the third place of the preferential list for five methods. Variant 10 was on the fourth and fifth place, accordingly. Only in the case of the method using elements of fuzzy logic and the ELECTRE method, variant 10 obtained the highest position. In the opinion of the authors of this paper, none of the users is going to check all ten variants generated by the software, but only the first three or four, as the closest to meeting their expectations. Therefore, the calculation method applied to order the decision variants should be the least labour-consuming, which is very easy using the ESORD tool.

\section{Conclusions}

Based on the conduced research and analyses, the following conclusions may be drawn:

1. Expectations of an assessor towards a specific decision variant are significantly dependent on their approach in a given decision-making situation.

2. Because of the specifics of design solutions in residential construction, a universal method allowing complex approach to the problem is not possible. In a given decision-making situation, it is possible to obtain a reliable assessment result and select the variant, which is the most adequate in relation to expectations of the future user of an apartment, formed in a specific criteria system.
3. Estimation of decision solutions in accordance with the specific assessment methods for the assumed decision-making situation is different mainly on the farther places of the preferential order, while the order of the first three or four variants is usually the same. Accordingly, taking into account high subjectivity in assessment of initial criteria, it can be stated that the assumptions made in this work have been met successfully.

4. The integrated multi-criteria assessment of design solutions for residential facilities introduced by the authors is susceptible to algorithmization, which allowed designing the IT tool (ESORD software).

\section{References}

Brauers, W. K. M.; Kildiene, S.; Zavadskas, E. K.; Kaklauskas, A. 2013. The construction sector in twenty European countries during the recession 2008-2009 - country ranking by Multimoora, International Journal of Strategic Property Management 17(1): 58-78.

Brown, M. A. 2012. Construction management: the management of the development, conservation and improvement of the built environment, Organization, Technology \& Management in Construction: an International Journal 4(2): 457-460.

Corriere, F.; Di Vincenzo, D.; Guerrieri, M. 2013. A logic fuzzy model for evaluation of the railway station's practice capacity in safety operating conditions, Archives of Civil Engineering LIX(1): 3-19.

Ghosh, S; Amaya, L.; Skibniewski, M. J. 2012. Identifying areas of knowledge governance for successful projects, Journal of Civil Engineering and Management 18(4): 495-504. http://dx.doi.org/10.3846/13923730.2012.700642

Gudienè, N.; Banaitis, A.; Podvezko, V.; Banaitiené, N. 2014. Identification and evaluation of the critical success factors for construction projects in Lithuania: AHP approach, Journal of Civil Engineering and Management 20(3): 350-359.

http://dx.doi.org/10.3846/13923730.2014.914082

Hashemkhani, Z. S.; Aghdaie, M. H.; Derakhti, A.; Zavadskas, E. K.; Varzandeh, M. H. M. 2013. Decision-making on business issues with foresight perspective; an application of new hybrid MCDM model in shopping mall locating, Expert Systems with Applications 40: 7111-7121. http://dx.doi.org/10.1016/j.eswa.2013.06.040

Hwang, C. L.; Yoon, K. 1981. Multiple attribute decisionmaking - methods and applications. A state of the art survey. Berlin, Heidelberg, New York: Springer Verlag. 250 p. http://dx.doi.org/10.1007/978-3-642-48318-9

Kaya, İ.; Kahraman, C. 2014. A comparison of fuzzy multicriteria decision making methods for intelligent building assessment, Journal of Civil Engineering and Management 20(1): 59-69.

http://dx.doi.org/10.3846/13923730.2013.801906

Kildienè, S.; Zavadskas, E. K.; Tamošaitienè, J. 2014. Complex assessment model for advanced technology deployment, Journal of Civil Engineering and Management 20(2): 280-290. http://dx.doi.org/10.3846/13923730.2014.904813

Kozielecki, J. 1977. Psychologiczna teoria decyzji. Warsaw: PWN. 498 p.

Krzemiński, M.; Książek, M. 2008. Wielokryterialna analiza wybranych obiektów budowlanych wraz z analiza kryteriów oceny przy zastosowaniu metody entropii [Multi- 
criteria analysis of selected works together with an analysis of evaluation criteria using the method of entropy]. Warsztaty Inżynierów Budownictwa, „Problemy przygotowania i realizacji inwestycji budowlanych" [Workshop of Civil Engineers "Problems of preparation and implementation of construction projects"], Pulawy, Poland. 15 p. (in Polish).

Książek, M. 2010a. Wielokryterialna ocena rozwiązań projektowych budynków [Multi-criteria evaluation of building design solutions]. PhD thesis. Wydawnictwa Politechniki Warszawskiej, Warsaw. 241 p. (in Polish).

Książek, M. 2010b. Ekspercki system oceny rozwiązań deweloperskich - wykorzystanie praktyczne [Expert evaluation system development solutions - use in practice], in Theoretical Foundations of Civil Engineering, PolishUkrainian Transactions, 13-17 September 2010, Krym, Ukraine, Vol. 18. CD. (in Polish).

Książek, M. 2011. Wykorzystanie wybranych metod wielokryterialnych do oceny inwestycji w procesie decyzyjnym [The use of selected methods for the evaluation of multicriteria decision-making investments], in Logistyka 3. CD. (in Polish).

Książek, M. 2010c. Wykorzystanie systemu informatycznego w procesie decyzyjnym [Use of the information system in decision-making], in Logistyka 6. CD. (in Polish).

Książek, M.; Nowak, P. 2009. Expert methods for design solutions assessment, in Logistyka 6. CD.

MacCrimmon, K. R. 1968. Decision marking among multipleattribute alternatives: A survey and consolidated approach. RAND Memorandum, RM-4823-ARPA. Santa Monica, California. 78 p.

Peng, K. H.; Tzeng, G. H. 2013. A hybrid dynamic MADM model for problem-improvement in economics and business, Technological and Economic Development of Economy 19(4): 638-660. http://dx.doi.org/10.3846/20294913.2013.837114

Radziszewska-Zielina, E. 2011. Assessment methods of partnering relations of Polish, Slovak and Ukrainian construction enterprises with the use of fuzzy logic, Archives of Civil Engineering LVII(1): 87-118.

Roy, B. 1991. The outranking approach and the foundations of ELECTRE methods, Theory and Decision 31: 49-73. http://dx.doi.org/10.1007/BF00134132

Saaty, T. L. 1994. Highlights and critical points in theory and application of the Analytic Hierarchy Process, European Journal of Operational Research 74: 426-447. http://dx.doi.org/10.1016/0377-2217(94)90222-4

Simanavičienè, R.; Liaudanskienè, R.; Ustinovičius, L. 2014. Assessing reliability of design, construction, and safety related decisions, Automation in Construction 39: 47-58. http://dx.doi.org/10.1016/j.autcon.2013.11.008

Turskis, Z.; Zavadskas, E. K.; Kutut, V. 2013. Model based on ARAS-G and AHP methods for multiple criteria prioritizing of heritage value, International Journal of Information Technology \& Decision Making 12(1): 45-73. http://dx.doi.org/10.1142/S021962201350003X

Tyszka, T. 1986. Analiza decyzyjna $i$ psychologia decyzji [Analysis and psychology of decisions]. Warsaw: PWN. 259 p. (in Polish).

Ustinovichius, L. 2004. Determination of efficiency of investments in construction, International Journal of Strategic Property Management 8(1): 25-44.

Ustinovichius, L. 2007. Methods of determining objective, subjective and integrated weights of attributes, International Journal of Management and Decision-Making 8(5/6): 540-554.

http://dx.doi.org/10.1504/IJMDM.2007.013417
Ustinovichius, L.; Zavadskas, E.; Migilinskas, D.; Malewska, A.; Nowak, P.; Minasowicz, A. 2006. Verbal analysis of risk elements in construction contracts, Cooperative Design, Visualization, and Engineering 4101: 295-302. http://dx.doi.org/10.1007/11863649_36

Ustinovichius, L.; Zavadskas, E. K.; Podvezko, V. 2007. Application of a quantitative multiple criteria decision-making (MCDM-1) approach to the analysis of investments in construction, Control and Cybernetics 36(1): 256-268.

Ustinovichius, L.; Barvidas A.; Vishnevskaja, A.; Ashikhmin, I. V. 2011. Multicriteria verbal analysis of territory planning system's models from legislative perspective, Journal of Civil Engineering and Management 17(1): 16-26. http://dx.doi.org/10.3846/13923730.2011.554173

Vodopivec, B.; Žarnić, R.; Tamošaitienè, J. 2014. Renovation priority ranking by multi-criteria assessment of architectural heritage: the case of castles, International Journal of Strategic Property Management 18(1): 88-100. http://dx.doi.org/10.3846/1648715X.2014.889771

Yazdani-Chamzini, A.; Fouladgar, M. M.; Zavadskas, E. K.; Haji Moini, S. H. 2013a. Selecting the optimal renewable energy using multi criteria decision-making, Journal of Business Economics and Management 14(5): 957-978. http://dx.doi.org/10.3846/16111699.2013.766257

Yazdani-Chamzini, A.; Razani, M.; Yakhchali, S. H.; Zavadskas, E. K.; Turskis, Z. 2013b. Developing a fuzzy model based on subtractive clustering for road header performance prediction, Automation in Construction 35: 111-120. http://dx.doi.org/10.1016/j.autcon.2013.04.001

Zadeh, L. A. 1978. Fuzzy sets as a basis for a theory of possibility, Fuzzy Sets and Systems 1: 3-28. http://dx.doi.org/10.1016/0165-0114(78)90029-5

Zadeh, L. A.; Fu, K. S.; Tanaka, K.; Shimura, M. (Eds). 1975. Fuzzy sets and their applications to cognitive and decision processes. New York: Academic Press. 496 p.

Zalewski, W. 2013. Applications of TOPSIS method in clustering of 24-hour loads in electric power distribution substations, Economics and Management 5(4): 101-110.

Zalewska, M.; Zalewski W. 2012. Application of the decision tree method in macroeconomics problems analysis, Economics and Management 4(4): 58-69.

Zavadskas, E. K.; Vainiunas, P.; Turskis, Z.; Tamošaitienė, J. 2012. Multiple criteria decision support system for assessment of projects managers in construction, International Journal of Information Technology \& DecisionMaking 11(2): 501-520.

http://dx.doi.org/10.1142/S0219622012400135

Zavadskas, E. K.; Turskis, Z.; Kildiené, S. 2014a. State of art surveys of overviews on MCDM/MADM methods, Technological and Economic Development of Economy 20(1): 165-179. http://dx.doi.org/10.3846/20294913.2014.892037

Zavadskas, E. K.; Vilutiene, T.; Turskis, Z.; Šaparauskas, J. 2014b. Multi-criteria analysis of projects' performance in construction, Archives of Civil and Mechanical Engineering 14: 114-121. http://dx.doi.org/10.1016/j.acme.2013.07.006

Zolfani, S. H.; Esfahani, M. H.; Bitarafan, M.; Zavadskas, E. K.; Arefi Sh., L. 2013. Developing a new hybrid MCDM method for selection of the optimal alternative of mechanical longitudinal ventilation of tunnel pollutants during automobile accidents, Transport 28(1): 89-96. http://dx.doi.org/10.3846/16484142.2013.782567 
Mariola Violeta KSIĄŻEK. PhD Eng. at Civil Engineering Faculty of Warsaw University of Technology (CEF WUT). Education: Civil Engineering, Construction Engineer, Speciality: Technology and Organisation of Building Works, (CEF WUT), 2001; Doctor of technical sciences, (CEF WUT), 2010. Research and teaching in the area of Cost estimation, Technology and organization in construction, Multi-criteria analysis and decision making assessment in construction, Quantitative and qualitative decision making methods, construction company management, Operational research.

Pawel Olaf NOWAK. PhD Eng. at Civil Engineering Faculty of Warsaw University of Technology (CEF WUT). Education: Civil Engineering, Construction Engineer, Speciality: Technology and Organisation of Building Works, (CEF WUT), 1993; Doctor of technical sciences, (CEF WUT), 2002; Vice Dean for Development at CEF WUT. Research interests: Multicriteria decision making in construction, Contractual issues in construction infrastructure projects, Operational research, Technology and Organisation of construction process, Quantitative and qualitative decision making methods, construction company management.

Serkan KIVRAK. Assistant Professor in the Civil Engineering Department at Anadolu University, Turkey. Education: Civil Engineering, Middle East Technical University, 1997; MSc (2005) and PhD (2010), Anadolu University, Civil Engineering, Construction Management Division. Research interests: Project management, Knowledge management, Health and safety in construction, Cross-cultural management, IT in construction.

Jerzy Hubert ROSŁON. MSc Eng. at Civil Engineering Faculty of Warsaw University of Technology (CEF WUT). Education: Civil Engineering, Construction Engineer, Speciality: Technology and Organisation of Building Works, (CEF WUT), 2013. Researcher and teaching fellow at CEF WUT. Research interests: Multicriteria decision making in construction, Operational research, Technology and organisation of construction process, Quantitative and qualitative decision making methods, construction company management, Optimization.

Leonas USTINOVICHIUS. Professor Dr Habil at Vilnius Gediminas Technical University. Education: Industrial and civil engineering, construction engineer, VISI (VGTU), 1982; Candidate of technical sciences Dnepropetrovsk ISI, 1989; Associate professor, VGTU, 1993; Doctor of technical sciences, VGTU, 1994; Doctor habilitatus, VGTU, 2003; Professor, VGTU, 2007. Research interests: Multicriteria evaluation and automated programming of technological decision in construction, Operational research methods, Technology of construction process, Quantitative and qualitative decision making methods, Organization and performance of construction firm. 